\title{
DOSEZI RAZUMNE PRILAGODBE (U DOMAĆEM, ANGLOSAKSONSKOM I PRAVU EUROPSKE UNIJE)
}

Prof. dr. sc. Ivana Grgurev*
UDK: $349.2:: 342.722 / .724>: 340.5$

349.2:316.647.82>:340.5

$349.2(4) \mathrm{EU}$

DOI: $10.3935 / z p f z .70 .23 .04$

Izvorni znanstveni rad

Primljeno: svibanj 2020.

U Republici Hrvatskoj zakonodavac, po uzoru na pravnu stečevinu Europske unije, pojam razumne prilagodbe izrijekom vezuje isključivo uz osobe s invaliditetom. S obzirom na razvoj antidiskriminacijskog prava, u ovom se radu polazi od teze da je vrijeme da se radi transparentnosti i bolje zaštite, izrijekom, propisima potvrdi da je taj pojam proširen i na druge ranjive skupine. $U$ radu se analiziraju obveze poslodavaca u pogledu prilagodbe mjesta $i$ uvjeta rada radnicima s invaliditetom $i$ radnicima pripadnicima drugih ranjivih skupina (radnicima vjernicima i radnicima s obiteljskim obvezama). Temi se pristupa usporednopravnom metodom upućujući na rješenja iz anglosaksonskog pravnog kruga. U dijelu rada koji se odnosi na pravo Europske unije pažnja se posvećuje novijoj legislativi i praksi Suda Europske unije kako bi se dokazalo da se, kad je riječ o razumnoj prilagodbi, pravo EU-a postupno otvara prema radnicima sobiteljskim obvezama i radnicima vjernicima. U kontekstu razmatranja obveza poslodavaca prema radnicima vjernicima, $u$ radu se posebna pažnja posvećuje prizivu savjesti koji se $u$ domaćoj pravnoj književnosti dosad nije promatralo kao oblik razumne prilagodbe.

Ključne riječi: razumna prilagodba, diskriminacija, priziv savjesti, anglosaksonsko pravo, pravna stečevina EU-a

* Dr. sc. Ivana Grgurev, profesorica Pravnog fakulteta Sveučilišta u Zagrebu, Trg Republike Hrvatske 14, 10000 Zagreb; ivana.grgurev@pravo.hr;

ORCID ID: orcid.org/0000-0001-5543-8518 


\section{UVOD}

Provođenje razumne prilagodbe (engl. reasonable accommodation; njem. angemessene Vorkehrungen) preduvjet je uključivanja (primarno) osoba s invaliditetom $\mathrm{u}$ društveni život. Pravno uređivanje razumne prilagodbe nije nova pojava. Naime, provedba razumne prilagodbe $u$ pojedinim usporednim pravnim sustavima postoji desetljećima (Kanada) ${ }^{1}$, a u većini država članica EU-a u posljednjih petnaestak godina. ${ }^{2}$ Ipak, i dalje postoje prijepori oko načina i opsega njezina provođenja. U radu se, stoga, objašnjavaju poslodavčeve obveze provođenja razumne prilagodbe mjesta i uvjeta rada za osobe s invaliditetom i pripadnike ostalih ranjivih skupina.

Rad je strukturiran na sljedeći način: nakon uvoda, u drugom poglavlju pojašnjava se pojam razumne prilagodbe u području rada i zapošljavanja, uključujući i trošak njezine provedbe. U trećem poglavlju analizira se kako pravna stečevina Europske unije uređuje razumnu prilagodbu, a u četvrtom poglavlju kako joj naš zakonodavac pristupa, pri čemu se fokus širi s prilagodbe za osobe s invaliditetom na prilagodbu za pripadnike ostalih ranjivih skupina. U tom dijelu rada pristupa se prizivu savjesti kao specifičnom obliku razumne prilagodbe za radnike čija se vjera i uvjerenje protive izvršavanju određenih poslovnih zadataka na njihovim radnim mjestima. U petom poglavlju upućuje se na napredna rješenja u anglosaksonskom pravnom krugu. Zaključno se zakonodavcu sugerira unapređenje propisa.

1 Bribosia, E.; Rorive, I., Reasonable Accommodation beyond Disability in Europe, European Commission, 2013., str. 14 i 40, https://op.europa.eu/en/publication-detail/-/publication/d7715f13-cd38-428e-873b-e2lb8c6ecb71/language-en (5. svibnja 2020.).

2 Nakon proteka razdoblja za implementaciju Direktive Vijeća 2000/78/EZ od 27. studenoga 2000. o uspostavi općeg okvira za jednako postupanje pri zapošljavanju i obavljanju zanimanja, SL L 303, 2. 12. 2000., dalje u tekstu: Direktiva 2000/78/ EZ ili Okvirna direktiva. Za naše nacionalno zakonodavstvo treba reći da je već u prvom tekstu Zakona o radu iz 1995. godine (Narodne novine, br. 38/1995) u čl. 77. st. 2. bila propisana obveza poslodavca da prilagodi poslove i uvjete rada radnikovu invaliditetu i sposobnostima. U kontekstu razumne prilagodbe za osobe s invaliditetom bitan je i Zakon o potvrđivanju Konvencije o pravima osoba s invaliditetom i Fakultativnog protokola uz Konvenciju o pravima osoba s invaliditetom (Narodne novine, Međunarodni ugovori, br. 6/2007). Ta je Konvencija u odnosu na Republiku Hrvatsku stupila na snagu 3. svibnja 2008. Objava o stupanju na snagu Konvencije o pravima osoba s invaliditetom i Fakultativnog protokola uz Konvenciju o pravima osoba s invaliditetom (Narodne novine, Međunarodni ugovori, br. 3/2008). 


\section{POJAM RAZUMNE PRILAGODBE / GRANICE POJMA RAZUMNE PRILAGODBE}

\subsection{Definicija razvijena u okviru zabrane diskriminacije osoba $s$ invaliditetom}

U pravilu (tako je u čl. 5. Direktive 2000/78/EZ i u čl. 4. Zakona o suzbijanju diskriminacije $\mathrm{e}^{3}$ ) pojam razumne prilagodbe vezuje se uz osobe s invaliditetom, iako postoje nacionalna zakonodavstva (tako je u SAD-u i Kanadi) ${ }^{4}$, koja obvezu razumne prilagodbe eksplicitno šire i na druge zabranjene osnove diskriminacije. ${ }^{5}$

U kontekstu zabrane diskriminacije na osnovi invaliditeta, razumna prilagodba predstavlja zahtjev za modifikacijom standarda usmjerenog isključivo osobama bez invaliditeta (engl. able-bodied norm) s ciljem ravnopravnog sudjelovanja osoba s invaliditetom u društvenom životu. ${ }^{6}$ Uključuje, u svijetu rada, prilagodbu sredstava rada ili, primjerice, radnog vremena ${ }^{7}$, uz uklanjanje arhitektonskih barijera. De Schutter definira razumnu prilagodbu kao obvezu usvajanja mjera radi prilagođavanja (javnih resursa, radnog mjesta, uvjeta rada i sl., op. I. G.) specifičnim potrebama osoba s invaliditetom bez nametanja nerazmjernog

3 Zakon o suzbijanju diskriminacije (Narodne novine, br. 85/2008, 112/2012). Dalje u tekstu: ZSD.

4 Detaljnije o tome dalje u tekstu u poglavlju 5. Razumna prilagodba u anglosaksonskom pravnom krugu.

5 U nas bi se prilagodba radnog mjesta trudnoj radnici predviđena u čl. 31. Zakona o radu (Narodne novine, br. 93/2014, 127/2017, 98/2019; dalje u tekstu: ZR) također trebala smatrati razumnom prilagodbom. Isto se odnosi i na obvezu poslodavca da maloljetnom radniku ponudi sklapanje ugovora o radu za obavljanje drugih odgovarajućih poslova kada maloljetnik obavlja poslove koji ugrožavaju njegovu sigurnost, zdravlje, ćudoređe ili razvoj (čl. 22. st. 3. ZR-a). Oblikom razumne prilagodbe radnicima određene vjere i uvjerenja treba smatrati i odredbe koja uređuje priziv savjesti sadržane u nizu zakona koji uređuju zdravstvenu struku. O tome detaljnije dalje u tekstu u poglavlju 4.3. Posebnosti priziva savjesti kao oblika razumne prilagodbe. Navedeno upućuje da su u nas konceptom razumne prilagodbe djelomice pokriveni, osim invaliditeta, i dob, spol te vjera i uvjerenje kao zabranjene osnove diskriminacije.

6 Društvo je ponajprije organizirano na osnovi potreba osoba bez invaliditeta. Bribosia; Rorive, op. cit. u bilj. 1, str. 5. Slično i: Fredman, S., Discrimination Law, Second Edition, Oxford University Press, Oxford, 2011., str. 95.

7 HK Danmark, C-335/11 i C-337/11 iz 2013., ECLI:EU:C:2013:222. O tom predmetu detaljnije dalje u tekstu. 
tereta onome tko je mjeru obvezan provesti. ${ }^{8}$ Njome se nastoji postići stvarna ravnopravnost (engl. substantive equality). ${ }^{9}$

Koncept razumne prilagodbe usko je vezan uz koncept neizravne diskriminacije, kojem je također cilj postizanje stvarne ravnopravnosti. ${ }^{10}$ Međutim, razlika između tih koncepata, a time i specifičnost razumne prilagodbe, jest u tome što je razumna prilagodba usmjerena na pojedinca ${ }^{11}$, dok je $\mathrm{u}$ fokusu neizravne diskriminacije ${ }^{12}$ stavljanje u nepovoljan položaj grupe ljudi. ${ }^{13}$ Razumna

8 De Schutter, O., International Human Rights Law, Second Edition, Cambridge University Press, Cambridge, 2014., str. 719.

9 O stvarnoj ravnopravnosti detaljnije u: Grgurev, I., Diskriminacija na temelju tjelesnih ili duševnih poteškoća u radnom pravu, Zbornik Pravnog fakulteta u Zagrebu, vol. 54, br. 3-4, 2004., str. 656 - 657. Stvarna (za razliku od formalne) ravnopravnosti, po Fredman, ima četiri cilja (tzv. četverodimenzionalni pristup ravnopravnosti). Jedan od njih je povećanje sudjelovanja podzastupljenih skupina u raznim područjima društvenog života (uključujući i politiku). Osim tog cilja, osobito izraženog kroz razumnu prilagodbu kao i kroz pozitivne mjere, ostali ciljevi stvarne ravnopravnosti su: ispravljanje nepovoljnog položaja, borba protiv stigmi, stereotipa, predrasuda i nasilja prema članovima zaštićenih skupina te promjena temeljnih struktura. Detaljnije u: Fredman, S., Pasts and futures: EU equality law, u: Bogg, A.; Costello, C.; Davies, A. C. L. (ur.), Research Handbook on EU Law, Edward Elgar, Cheltenham, 2016., str. 392. Kako Fredman spominje i nasilje prema članovima ranjivih skupina u društvu, u tom kontekstu treba naglasiti kako se sprečavanjem nasilja (i uznemiravanja) u svijetu rada intenzivno bavi Međunarodna organizacija rada. Vidjeti Konvenciju o nasilju i uznemiravanju br. 190 i preporuku br. 206 istog naziva, usvojene 2019. godine: https:/www.ilo.org/dyn/normlex/en/f?p=NORMLEXPUB:1210 0:0::NO:12100:P12100_INSTRUMENT_ID:3999810:NO (4. srpnja 2019.), https:// www.ilo.org/dyn/normlex/en/f?p=NORMLEXPUB:12100:0::NO:12100:P12100_ INSTRUMENT_ID:4000085:NO (4. srpnja 2019.).

10 Bribosia; Rorive, op. cit. u bilj. 1, str. 5.

11 Barnard naglašava činjenicu postojanja raznih oblika invaliditeta te stoga jedno pravilo ne možemo primijeniti na sve situacije. Barnard, C., EU Employment Law, Fourth Edition, Oxford University Press, Oxford, 2012., str. 345. Individualni pristup, koji leži u osnovi razumne prilagodbe, komplicira prilagodbu, ali jedini osigurava zapošljavanje osoba s invaliditetom. Osobe s invaliditetom imaju značajnu ulogu u razumnoj prilagodbi mjesta i uvjeta rada jer su same u mogućnosti predložiti poslodavcu kakvu prilagodbu trebaju.

12 Detaljnije o neizravnoj diskriminaciji u: Potočnjak, Ž.; Grgić, A., Osnovni pojmovi i koncepcije o zabrani diskriminacije u radnom pravu, u: Potočnjak, Ž.; Grgurev, I.; Grgić A. (ur.), Perspektive antidiskriminacijskog prava, Pravni fakultet Sveučilišta u Zagrebu, Zagreb, 2014., str. 15 - 17.

13 Slično Bribosia; Rorive, op. cit. u bilj. 1. 
prilagodba ima i određenu sličnost s pozitivnim mjerama ${ }^{14}$, međutim, one su privremenog karaktera (primjenjuju se dok neravnopravnost ne prođe), a kod razumne prilagodbe nije tako.

Za razliku od prava EU-a, propust provedbe razumne prilagodbe predstavlja, u međunarodnom i nacionalnom pravu, diskriminaciju na osnovi invaliditeta (čl. 2. UN-ove Konvencije o pravima osoba s invaliditetom i čl. 4. st. 2. ZSD-a, za razliku od čl. 5. Direktive 2000/78/EZ). ${ }^{15}$

\subsection{Razmjernost tereta / trošak razumne prilagodbe}

Bitan element definicije razumne prilagodbe jest razmjernost tereta poduzetih mjera. Navedeno je definirano u okviru pravne stečevine EU-a u čl. 5. Direktive 2000/78/EZ, a u nas u čl. 4. st. 2. ZSD-a. Naime, prilagodba je razumna dok ne predstavlja nerazmjeran teret za onoga tko je to dužan omogućiti (arg. iz čl. 4. st. 2. ZSD-a).

Ocjenjujući što je razumno, a što nerazumno u kontekstu antidiskriminacijskog prava, treba reći kako je izravna diskriminacija iracionalna jer predstavlja djelovanje suprotno od tržišnih principa. ${ }^{16}$ Da pojasnim. Ako, primjerice, poslodavac pri zapošljavanju umjesto najboljeg kandidata (kojeg bi zaposlio da je primijenio kriterije sposobnosti, znanja i vještina), zaposli onog koji je preostao primjenjujući diskriminacijske osnove kao kriterije za zasnivanje radnog odnosa, tada sebi čini štetu. Stoga je potrebno osvijestiti poslodavce da pri provođenju odluka vezanih uz rad i zapošljavanje ne čine sami sebi štetu, već da primjenjuju isključivo kriterije vezane uz produktivnost (engl. merit-based criteria; criteria related to productivity). Međutim, provođenje razumne prilagodbe često je povezano uz trošak. Ako je financijski teret provođenja razumne prilagodbe teret poslodavca, propuštanje provođenja razumne prilagodbe čini se razumnom odlukom

14 Detaljnije o pozitivnim mjerama u: Potočnjak, Ž.; Grgić, A., Izuzeci i opravdanja kod zabrane diskriminacije, u: Potočnjak, Ž.; Grgurev, I.; Grgić, A. (ur.), Perspektive antidiskriminacijskog prava, Pravni fakultet Sveučilišta u Zagrebu, Zagreb, 2014., str. $172-174$.

15 U pravnoj teoriji postoje prijepori oko toga predstavlja li propuštanje razumne prilagodbe izravnu ili neizravnu diskriminaciju ili je pak riječ o posebnom obliku diskriminacije. Bribosia; Rorive, op. cit. u bilj. 1, str. 8.

16 O iracionalnosti izravne diskriminacije vidi: Somek, A., Rationalität und Diskriminierung, Springer, Wien, 2001. Vidi i: Zatz, N. D., Discrimination and Labour Law: Locating the Market in Maldistribution and Subordination, u: Collins, H.; Lester, G.; Mantouvalou, V. (ur.), Philosophical Foundations of Labour Law, Oxford University Press, Oxford, 2018., str. 159. 
poslodavca (promatrano isključivo s ekonomskog aspekta). Zato propisi koji uređuju to područje moraju uključivati subvencioniranje kako bi bili poticajni za provođenje razumne prilagodbe. ${ }^{17}$ Granice obveze provođenja razumne prilagodbe pojašnjene su u čl. 5. Direktive 2000/78/EZ: “Taj se teret neće smatrati nerazmjernim ako se u dovoljnoj mjeri podupre postojećim mjerama politike za zaštitu osoba s invaliditetom dotične države članice." Dakle, ako postoji adekvatan način sufinanciranja razumne prilagodbe od strane države, teže će poslodavac argumentirati da mu prilagodba mjesta i uvjeta rada za osobe s invaliditetom predstavlja nerazmjeran teret.

Vrhovni sud Kanade protumačio je "nerazmjeran teret" (engl. undue hardship), primjerice, navodeći čimbenike koji su od utjecaja na ocjenu njegova postojanja, poput ograničenih financijskih i materijalnih sredstava, ograničavanja prava trećih osoba i želje da se osigura učinkovitost trgovačkog društva ili institucije. ${ }^{18}$ "Konkretni materijalni dokazi nerazmjernog tereta moraju se dostaviti; puke hipoteze i spekulacije nisu dostatne." ${ }^{19}$

U SAD-u od 1990. postoji propis koji, među ostalim, obvezuje poslodavce da provode razumnu prilagodbu (Americans with Disability Act).$^{20}$ Taj propis definira pojam razumne prilagodbe (čl. 12111. st. 9.) ${ }^{21}$ i pojam nerazmjernog tereta (čl. 12111. st. 10.). Pojednostavljeno, nerazmjeran teret predstavljaju mjere koje dovode do značajnih teškoća ili troška uzimajući u obzir određene čimbenike: prirodu i troškove prilagodbe, opremu kojom poslodavac raspolaže, financijska sredstva poslodavca, broj radnika i vrstu djelatnosti kojom se poslodavac bavi. ${ }^{22}$

17 O poticajima za zapošljavanje osoba s invaliditetom vidi Izvješće o radu Pravobranitelja za osobe s invaliditetom za 2018. godinu, str. 177 - 183. Pojedini poticaji iznimno su slabo korišteni od strane poslodavaca kao što je poticaj financiranja stručne podrške koji je u 2018. godini koristio samo jedan poslodavac za jednu osobu s invaliditetom. Slabo korištenje poticaja upućuje na to da su loše formulirani te da ih treba učiniti atraktivnima za poslodavce.

18 Brunelle, citirano prema: Bribosia; Rorive, op. cit. u bilj. 1, str. 17.

19 Brunelle, citirano prema: Bribosia; Rorive, op. cit. u bilj. 1, str. 18.

20 Tekst zakona dostupan na: http://www.ada.gov/pubs/adastatute08.htm (18. travnja 2020.) Detaljnije u: Grgurev, op. cit. u bilj. 9, str. 666 - 671.

21 Pod pojmom razumne prilagodbe misli se na omogućavanje osobama s invaliditetom da postojećoj opremi poslodavca pristupe i njome se koriste, restrukturiranje posla, omogućavanje rada sa skraćenim radnim vremenom ili na drugi način modificiranje rasporeda radnog vremena, raspored na druge odgovarajuće poslove, nabava ili modifikacija opreme i sl.

22 Niz istraživanja provedenih u SAD-u pokazao je kako razumna prilagodba u velikom broju slučajeva ne košta ništa. Tako je u istraživanju provedenom na uzorku od 776 poslodavaca, a objavljenom 2019. godine, $58 \%$ anketiranih poslodavaca 


\section{RAZUMNA PRILAGODBA U PRAVNOJ STEČEVINI EU-a}

\subsection{Razumna prilagodba namijenjena osobama s invaliditetom}

Razumna prilagodba u pravu EU-a uređena je čl. 5. Direktive 2000/78/EZ. ${ }^{23}$ Zabrana diskriminacije na osnovi invaliditeta ograničen je koncept u pravu EU-a jer se odnosi isključivo na područje rada i zapošljavanja (a ne i na ostala područja društvenog života kao što su obrazovanje, socijalna sigurnost, pristup dobrima i uslugama). Od 2008. godine postoji Prijedlog za donošenje Direktive o uvođenju načela ravnopravnosti između osoba bez obzira na vjeru ili uvjerenje, invalidnost, dob ili spolnu orijentaciju. ${ }^{24}$ Navedeni Prijedlog predviđa proširenje zabrane diskriminacije, među ostalim, i po osnovi invaliditeta i na druga područja društvenog života. Kako ta direktiva nije usvojena duže od desetljeća, otvara se pitanje zašto je tako. Izostanak političke volje država članica za usvajanjem predložene direktive, nedvojbeno, posljedica je njihove bojazni od financijskih implikacija širenja te zabrane. ${ }^{25}$ Osim činjenice da je u pravu EU-a na osnovi invaliditeta zabranjeno diskriminirati samo u području rada i zapošljavanja, kao

izjavilo da nisu imali nikakve troškove vezane uz razumnu prilagodbu, dok je 37 \% anketiranih poslodavaca izjavilo da su imali jednokratni trošak prilagodbe koji nije premašio 500 dolara. $\mathrm{Na}$ upit da usporede troškove za radnika s invaliditetom $\mathrm{u}$ odnosu na troškove za radnika bez invaliditeta na istom radnom mjestu, poslodavci u SAD-u odgovaraju da ta razlika iznosi u prosjeku 100 dolara, koliko je potrebno više izdvojiti za radnika s invaliditetom. Workplace Accommodations: Low Cost, High Impact, Job Accommodation Network, ODEP, 2019., str. 3, https://askjan.org/ publications/Topic-Downloads.cfm?pubid=962628 (2. svibnja 2020.).

23 Tekst te odredbe glasi: "Kako bi se zajamčilo poštovanje načela jednakog postupanja u pogledu osoba s invaliditetom, moraju se osigurati razumne prilagodbe njihovim posebnim potrebama. To znači da poslodavci prema potrebi u određenoj situaciji poduzimaju odgovarajuće mjere kako bi se osobi s invaliditetom omogućio pristup zapošljavanju, sudjelovanje ili napredovanje na radu ili usavršavanje, ako takve mjere za poslodavca ne predstavljaju nerazmjeran teret. Taj se teret neće smatrati nerazmjernim ako se $\mathrm{u}$ dovoljnoj mjeri podupre postojećim mjerama politike za zaštitu osoba s invaliditetom dotične države članice."

24 Proposal for a Council Directive on implementing the principle of equal treatment between persons irrespective of religion or belief, disability, age or sexual orientation SEC(2008)2180, http://eur-lex.europa.eu/legal-content/en/TXT/?uri=CELEX:52008PC0426 (20. ožujka 2020.).

25 "Mnoge države članice iskazale su rezerve vezano uz pravnu jasnoću Prijedloga i tražile dodatne informacije o njegovim financijskom implikacijama." Quinne, G.; Waddington, L. (ur.), European Yearbook of Disability Law, sv. 1, Intersentia, Antwerp, 2009., str. 164. 
daljnji nedostatak treba navesti i to kako je diskriminacija na osnovi invaliditeta uređena Okvirnom direktivom (što znači da ona ujedno uređuje i zabranu po drugim osnovama: dobi, vjeri/uvjerenju i spolnoj orijentaciji). Stoga, na razini EU-a postoji potreba za usvajanjem pravnog instrumenta koji bi se isključivo nosio sa specifičnostima diskriminacije osoba s invaliditetom (kao što se to čini s rasom/etničkim podrijetlom i spolom jer su te osnove svaka za sebe uređene zasebnim direktivama posvećenim njihovim specifičnostima). ${ }^{26}$

Da bi poslodavac pristupio razumnoj prilagodbi, treba znati kome je razumna prilagodba namijenjena. Postavlja se pitanje znaju li poslodavci što pripada u pojam invaliditeta (pripadaju li, primjerice, karcinom, HIV, multipla skleroza ili pretilost u taj pojam? $)^{27}$ i, posljedično, prema kome su obvezni provesti razumnu

26 Vidi Direktivu Vijeća 2000/43/EZ od 29. lipnja 2000. o provedbi načela jednakog postupanja prema osobama bez obzira na njihovo rasno ili etničko podrijetlo (OJ L 180, 19. srpnja 2000., str. 19 - 23) i Direktivu 2006/54/EZ Europskog parlamenta i Vijeća od 5. srpnja 2006. o provedbi načela jednakih mogućnosti i jednakog postupanja prema muškarcima i ženama u pitanjima zapošljavanja i rada (preinaka), OJ L 204, 26. srpnja 2006., str. 23 - 26.

27 U predmetu Kaltoft, C-354/13, ECLI:EU:C:2014:2463 Sud EU-a presudio je da i pretilost pripada $\mathrm{u}$ invaliditet ako sprečava sudjelovanje u profesionalnom životu: "Direktivu Vijeća 2000/78/EZ ... treba tumačiti u smislu da pretilost radnika predstavlja "invaliditet" u smislu te direktive kada on predstavlja ograničenje koje proizlazi iz dugotrajnih tjelesnih, mentalnih ili psihičkih oštećenja, čije međudjelovanje s različitim preprekama može sprečavati puno i učinkovito sudjelovanje osobe $\mathrm{u}$ pitanju u profesionalnom životu na ravnopravnoj osnovi s drugim radnicima. Na sudu koji je uputio zahtjev je da provjeri jesu li u glavnom predmetu ti uvjeti ispunjeni." Sud Europske unije, osim u tom predmetu, u više je navrata odlučivao o pojmu invaliditeta. Tako je u predmetu Chacón Navas (C-13/05), o kojem je odlučivao prije nego što je EU ratificirao UN-ovu Konvenciju o pravima osoba s invaliditetom, presudio da dugotrajno bolovanje nije invaliditet. U novijem predmetu Daouidi (C-395/15) španjolski je sud pitao Sud EU-a treba li Direktivu 2000/78 tumačiti na način da činjenica da je osoba privremeno nesposobna za rad, u smislu nacionalnog prava, na neodređeno vrijeme, zbog ozljede na radu, sama po sebi implicira da se ograničenja sposobnosti te osobe može kvalificirati "trajnim” u smislu pojma "invaliditeta" iz te direktive. Sud EU-a u tom je predmetu dao smjernice nacionalnom sudu za utvrđivanje postoji li trajno ograničenje sposobnosti u smislu pojma invaliditeta (jer je riječ o činjeničnoj ocjeni) i naglasio da se ono mora tumačiti autonomno i ujednačeno na razini EU-a jer ono nije prepušteno nacionalnim pravima država članica. "Među indicijama koje omogućavaju smatrati da je takvo ograničenje "trajno" nalazi se osobito činjenica da na datum navodno diskriminatorne činjenice nije jasno određen kratkoročni završetak nesposobnosti dotične osobe, ili činjenica da se ta nesposobnost može značajno produžiti prije oporavka navedene osobe, i u okviru provjere te "trajne" naravi, sud koji je uputio zahtjev treba temeljiti svoju odluku na ukupnosti objektivnih elementa kojima raspolaže, 
prilagodbu. U kontekstu rada i zapošljavanja Sud EU-a razvio je test po kojem bi sve navedeno moglo predstavljati invaliditet kada predstavlja ograničenje koje proizlazi iz dugotrajnih tjelesnih, mentalnih ili psihičkih oštećenja, čije međudjelovanje s različitim preprekama može sprečavati puno i učinkovito sudjelovanje određene osobe $u$ profesionalnom životu na ravnopravnoj osnovi s drugim radnicima. ${ }^{28}$

EU od 2009. obvezuje UN-ova Konvencija o pravima osoba s invaliditetom koja je, po svojem pristupu zabrani diskriminacije na osnovi invaliditeta, suvremen (jer, među ostalim, pri definiranju invaliditeta koristi socijalni, a ne medicinski model) i složen pravni instrument (jer jamči niz prava kojima je svrha uključivanje osoba s invaliditetom u sve sfere društvenog života). Navedeno stvara obvezu na strani Suda EU-a da tumači pravnu stečevinu, dakle, i Direktivu 2000/78/EZ u skladu s tom Konvencijom. Tako je Sud EU-a postupio u poznatom predmetu HK Danmark ${ }^{29}$, u kojem je presudio kako je skraćivanje radnog vremena radnicama s invaliditetom oblik razumne prilagodbe.

Pojedini autori upozoravaju na razlike u pristupu razumnoj prilagodbi $u$ pravu EU-a u odnosu na UN-ovu Konvenciju o pravima osoba s invaliditetom te ističu manjkavosti prava EU-a (osobito činjenicu da Direktiva 2000/78/EZ, za razliku od Konvencije, propuštanje razumne prilagodbe ne definira kao oblik diskriminacije). ${ }^{30}$

\subsection{Razumna prilagodba namijenjena radnicima s obiteljskim obvezama i radnicima vjernicima}

Direktiva o ravnoteži između poslovnog i privatnog života roditelja i pružatelja skrbi31, među ostalim, predviđa jedan oblik razumne prilagodbe i za

osobito na dokumentima i potvrdama koje se odnose na stanje te osobe, sastavljenih na temelju aktualnih medicinskih i znanstvenih saznanja i podataka." Paragraf 59 presude u predmetu Daouidi, ECLI:EU:C:2016:917.

28 Vidi predmet Kaltoft, op. cit.

C-335/11 i C-337/11, ECLI:EU:C:2013:222.

30 Waddington, L.; Broderick, A., Combatting disability discrimination and realising equality, A comparison of the UN Convention on the Rights of Persons with Disabilities and EU equality and non-discrimination law, European Commission, 2018., str. 70 i 71, https:// ec.europa.eu/info/sites/info/files/combatting_disabiliy_discrimination.pdf (12. srpnja 2019.).

31 Direktiva (EU) 2019/1158 Europskog parlamenta i Vijeća od 20. lipnja 2019. o ravnoteži između poslovnog i privatnog života roditelja i pružatelja skrbi i o stavljanju 
radnike s obiteljskim obvezama, dok Sud EU-a u predmetu Achbita ${ }^{32}$ navodi kakvu prilagodbu EU traži od poslodavaca za radnike vjernike. Riječ je o segmentarnom pristupu prilagodbi. Da pojasnim. Direktiva o ravnoteži prvi je pravni izvor EU-a koji predviđa dopust za radnike koji pružaju skrb ovisnim članovima obitelji (a da to nisu djeca). Dosad je direktivama zaštita bila pružana samo zaposlenim roditeljima. ${ }^{33}$

Tezu da se u pravu EU-a obveza razumne prilagodbe djelomice širi i na radnike vjernike potvrđuje presuda u predmetu Achbita. Naime, Sud EU-a u tom je predmetu, koji se odnosi na radnicu koja je, usprkos poslodavčevoj politici neutralnosti, ustrajala na nošenju muslimanske marame na radnom mjestu na kojem je bila u vizualnom kontaktu s klijentima (rad na recepciji), zatražio od nacionalnog suda da utvrdi je li poslodavac mogao, umjesto otkaza, ponuditi radnici drugo odgovarajuće radno mjesto. ${ }^{34}$ Navedeno držim oblikom prilagodbe. ${ }^{35}$ Može se zaključiti da EU traži određenu prilagodbu na radnom mjestu za

izvan snage Direktive Vijeća 2010/18/EU, OJ L 188, 12. srpnja 2019., str. 79 - 93. Dalje u tekstu: Direktiva o ravnoteži.

32 Achbita, C-157/15, ECLI:EU:C:2017:203. Vezano uz vjerske slobode i zabranu diskriminacije na temelju vjere na radnom mjestu vidi mišljenje nezavisne odvjetnice Kokott u predmetu Achbita, C- 157/15 od 31. svibnja 2016. U tom se predmetu jasno vidi veza između spola i vjere, što otvara pitanje intersekcijske diskriminacije. O tom obliku diskriminacije više u: Vasiljević, S., Pravno uređenje višestruke diskriminacije u proširenoj Europskoj uniji (doktorska disertacija), Pravni fakultet Sveučilišta u Zagrebu, Zagreb, 2008.

33 Direktiva Vijeća 92/85/EEZ od 19. listopada 1992. o uvođenju mjera za poticanje poboljšanja sigurnosti i zdravlja na radu trudnih radnica te radnica koje su nedavno rodile ili doje, OJ L 348, 28. studenoga 1992., str. 1 - 7, i izvan snage stavljena Direktiva Vijeća 2010/18/EU od 8. 3. 2010. o provedbi revidiranog sporazuma o roditeljskom dopustu koji su sklopili BUSINESSEUROPE, UEAPME, CEEP i ETUC te o stavljanju izvan snage Direktive 96/34/EZ, OJ L 68, 18. ožujka 2010., str. 13 - 20.

34 Paragraf 43 predmeta Achbita. Uz taj predmet treba spomenuti i predmet Bougnaoui (C-188/15, ECLI:EU:C:2017:204) jer se također odnosi na radnicu koja je ustrajala na nošenju muslimanske marame na radnom mjestu, usprkos želji klijenta da je ne nosi. Dalje u tekstu ne analizira se taj predmet jer pitanje nacionalnog suda, upućeno Sudu EU-a u tom predmetu, nije išlo u smjeru obveze prilagodbe uvjeta rada radnici, već je nacionalni sud zanimalo treba li želju klijenta smatrati stvarnim i odlučujućim uvjetom za obavljanje zanimanja. Sud EU-a ispravno zaključuje kako to ne može biti stvarni i odlučujući uvjet.

35 Na ovom mjestu pojam 'razumno' izostavljam jer zapošljavanje radnica koje svojom odjećom jasno izražavaju pripadnost određenoj vjeri (islamu) samo na vizualno beskontaktnim radnim mjestima vodi njihovoj izolaciji, što je u neskladu s idejom zabrane diskriminacije i teško se može nazvati razumnim. 
radnike s obiteljskim obvezama i za radnike vjernike. Nažalost, nema mjesta entuzijazmu. Naime, dopust za radnike s obiteljskim obvezama (Direktiva ih naziva 'pružateljima skrbi') simboličan je (5 radnih dana godišnje) ${ }^{36}$, a nuđenje radnicama, koje nose islamske marame za glavu, radnih mjesta na kojima nemaju vizualni kontakt s klijentima samo je formalna, ne i učinkovita razumna prilagodba jer nije inkluzivna niti predstavlja stvarno prihvaćanje raznolikosti. ${ }^{37}$

\section{RAZUMNA PRILAGODBA U HRVATSKOM PRAVU}

\subsection{Razumna prilagodba za radnike s invaliditetom}

Za razliku od prava EU-a, po kojem je zabranjeno diskriminirati na osnovi invaliditeta samo u području rada i zapošljavanja, u nas je prihvaćen širi koncept zabrane diskriminacije osoba s invaliditetom koji obuhvaća sva područja društvenog života (čl. 4. st. 2. i čl. 8. ZSD-a). Razumna prilagodba obveza je poslodavca i po čl. 12. st. 4. u svezi s čl. 7. st. 2. Zakona o profesionalnoj rehabilitaciji i zapošljavanju osoba s invaliditetom ${ }^{38}$, kao i po čl. 4l. st. 2. ZR-a. Sufinanciranje troškova prilagodbe uređeno je Pravilnikom o poticajima pri zapošljavanju osoba s invaliditetom. ${ }^{39}$

36 Čl. 6. Direktive o ravnoteži.

37 U tom kontekstu vrijedi spomenuti Rezoluciju 2076 Parlamentarne skupštine Vijeća Europe od 30. 9. 2015. naslovljenu 'Sloboda vjere i zajednički život u demokratskom društvu' (Freedom of religion and living together in a democratic society). U njoj Parlamentarna skupština poziva države članice Vijeća Europe na razumnu prilagodbu vjernicima kako bi im se zajamčila ravnopravnost u slobodi vjere na učinkovit, a ne samo formalan način. Nadalje, traži od država članica da osiguraju neutralnost koja je inkluzivna i prihvaća raznolikosti. Tekst Rezolucije dostupan je na: https://assembly.coe.int/nw/xml/XRef/Xref-XML2HTML-en.asp?file$\mathrm{id}=22199 \&$ lang $=$ en (16. travnja 2020.).

38 Zakon o profesionalnoj rehabilitaciji i zapošljavanju osoba s invaliditetom (Narodne novine, br. 153/2013, 152/2014, 39/2018, 32/2020). Dalje u tekstu: ZPRZOI. Vidi i: Priručnik preporuka za razumnu prilagodbu radnog mjesta, Zavod za vještačenje, profesionalnu rehabilitaciju i zapošljavanje osoba s invaliditetom i Ministarstvo rada i mirovinskog sustava, 2018., https://www.zosi.hr/docs/prirucnik_s_preporukama_za_razumnu_prilagodbu_radnog_mjesta.pdf (10. svibnja 2020.).

39 Pravilnik o poticajima pri zapošljavanju osoba s invaliditetom (Narodne novine, br. 75/2018, 120/2018). Osim navedenog, postoji i niz pravilnika koji su usmjereni poticanju zapošljavanja osoba s invaliditetom: Pravilnik o utvrđivanju kvota za zapošljavanje osoba s invaliditetom (Narodne novine, br. 75/2018, 120/2018, 27/2020), Pravilnik o zaštitnim radionicama i integrativnim radionicama za zapošljavanje osoba s invaliditetom (Narodne novine, br. 75/2018) i Pravilnik o profesio- 
Osim obveze provođenja razumne prilagodbe postoji niz pozitivnih mjera (kao što su sustav kvota i prednosti pri zapošljavanju ${ }^{40}$ usmjerenih uključivanju osoba s invaliditetom u društveni život (engl. social inclusion). Međutim, te su pozitivne mjere neprovedive ako izostane razumna prilagodba u sustavu obrazovanja. Pravobraniteljica za osobe s invaliditetom u svojim godišnjim izvješćima upozorava na propuste u provođenju razumne prilagodbe za djecu s teškoćama u razvoju u svim segmentima obrazovnog sustava, od predškolskog do visokog obrazovanja. ${ }^{41}$

Treba spomenuti i ostale (u praksi slabo korištene) institute koji mogu pomoći pri zapošljavanju osoba s invaliditetom poput profesionalne rehabilitacije ${ }^{42}$ te rada kod kuće (čl. 17. ZR-a), za koji ipak treba istaknuti kako u sebi nosi opasnost društvene izolacije osoba s invaliditetom.

Domaća sudska praksa u ovom je području skromna. Ipak, izdvaja se jedan predmet $\mathrm{u}$ kojem se povezuje propuštanje razumne prilagodbe s uznemiravanjem na osnovi invaliditeta. Prema Županijskom sudu u Zagrebu 'povreda obveze razumne prilagodbe dovoljna je da sud pretpostavi da je nepovoljno postupanje u smislu nastanka neprijateljskog radnog okruženja moglo biti uvjetovano suspektnom osnovom invaliditeta. ${ }^{73}$ Iz citiranog proizlazi da je sud u konkretnom slučaju prihvatio da je prima facie dokazano da je do uznemiravanja došlo upravo na osnovi invaliditeta jer je poslodavac propustio razumnu prilagodbu. Nadalje, zabrinjava što sama država propušta provoditi razumnu prilagodbu i na taj način diskriminira osobe $s$ invaliditetom. Javnosti je poznat predmet $u$

nalnoj rehabilitaciji i centrima za profesionalnu rehabilitaciju (Narodne novine, br. 75/2018).

41 Vidi Izvješće o radu Pravobranitelja za osobe s invaliditetom za 2018. godinu, str. 118. Pravobraniteljica je zaprimila pritužbe na sustav predškolskog odgoja, koje su se odnosile na nemogućnost upisa u vrtić ili duže čekanje na upis, kvalitetu rada djelatnika i odnos prema djetetu s teškoćama u razvoju te razumnu prilagodbu djetetovim potrebama. U istom se Izvješću navode i slučajevi propuštanja razumne prilagodbe za djecu s teškoćama u razvoju u osnovnoškolskom (str. 127 - 134), srednjoškolskom (str. 134 - 136) i visokom obrazovanju (str. 140 - 148).

42 Čl. 44. - čl. 55. Zakona o mirovinskom osiguranju (Narodne novine, br. 157/2013, 151/2014, 33/2015, 93/2015, 120/2016, 18/2018, 62/2018, 115/2018, 102/2019) i čl. 4. - čl. 6. ZPRZOI-ja. Detaljnije u: Bejaković, P., Studija isplativosti profesionalne rehabilitacije u Republici Hrvatskoj, Fond za profesionalnu rehabilitaciju i zapošljavanje osoba s invaliditetom, Zagreb, 2013.

43 Županijski sud u Zagrebu, Gžr-1708/16-2, 20. 12. 2016. Citirano prema: Vasiljević, S.; Vinković, M., Temeljna prava i zabrana diskriminacije u praksi europskih $i$ nacionalnih sudova, Narodne novine, Zagreb, 2019., str. 158. 
kojem je naloženo Republici Hrvatskoj da ukloni arhitektonske barijere ispred Upravnog suda u Rijeci jer je zgrada suda bila neprilagođena osobama u invalidskim kolicima. ${ }^{44}$

Iz navedenog zaključujem kako je propisima (zakonskim i podzakonskim, a u manjoj mjeri i sudskom praksom) pravo na razumnu prilagodbu uvjeta i mjesta rada osobama s invaliditetom u nas detaljno razrađeno. Dalje u tekstu odgovara se na pitanje jamče li naši propisi pripadnicima drugih ranjivih skupina pravo na razumnu prilagodbu mjesta i uvjeta rada.

\subsection{Razumna prilagodba uvjeta rada po drugim osnovama, različitim od invaliditeta}

Iako zakonodavac eksplicitno ne spominje razumnu prilagodbu izvan konteksta zapošljavanja i rada osoba s invaliditetom, razni oblici prilagodbe namijenjeni pripadnicima ostalih ranjivih skupina uređeni su nacionalnim zakonodavstvom. Tako, primjerice, trudne radnice i radnici vjernici uživaju određene pogodnosti koje bi trebalo smatrati oblicima razumne prilagodbe jer bi njima bez tih mjera bilo značajno otežano ili onemogućeno sudjelovanje u svijetu rada.

Kod prava trudnica u određenim slučajevima nema razgraničenja između zaštite na radu i razumne prilagodbe. Primjerice, to je slučaj kod obveze poslodavca da ponudi dodatak ugovora o radu kojim će na određeno vrijeme ugovoriti obavljanje drugih odgovarajućih poslova kad trudnica radi na poslovima koji ugrožavanju njezino i/ili zdravlje djeteta (čl. 31. st. 1. ZR-a). Pravo na slobodne dane radnika pripadnika vjerskih manjina, također, oblik je prilagodbe uvjeta rada po osnovi vjere. ${ }^{45}$

44 Županijski sud u Puli, Gž-67/17-2, 27. 3. 2017.

45 Prema čl. 3. Zakona o blagdanima, spomendanima i neradnim danima u Republici Hrvatskoj (Narodne novine, br. 110/2019) radnici pravoslavne vjeroispovijesti (iako zakonodavac kaže da to pravo imaju kršćani, zapravo to pravo pripada radnicima pravoslavne vjeroispovijesti) imaju pravo ne raditi kad slave Božić (7. 1.) i Uskrsni ponedjeljak po julijanskom kalendaru, radnici islamske vjeroispovijesti imaju pravo ne raditi u dane Ramazanskog bajrama i Kurban-bajrama, dok radnici židovske vjeroispovijesti imaju pravo ne raditi u dane Roš Hašane i Jom Kipura. U te dane kada ne rade imaju pravo na naknadu plaće (čl. 5.). U kontekstu prava radnika vjernika na neradne dane treba spomenuti i presudu Suda EU-a u predmetu Cresco (C-193/17, ECLI:EU:C:2019:43) od 22. siječnja 2019. U tom je predmetu Sud EU-a utvrdio kako je austrijsko zakonodavstvo diskriminirajuće jer je njime predviđen Veliki petak kao neradni dan samo za radnike koji su pripadnici određenih kršćanskih crkava i samo ti radnici, ako moraju raditi tijekom tog neradnog dana, imaju pravo na dodatnu naknadu plaće isplaćene za rad obavljen tijekom toga dana. Sporna 


\subsection{Posebnosti priziva savjesti kao oblika razumne prilagodbe}

Pravo na priziv savjesti ${ }^{46} \mathrm{ni}$ u propisima ni u pravnoj književnosti, iako ima sve elemente pojma razumne prilagodbe, ne kvalificira se kao oblik prilagodbe uvjeta rada radnicima kojima vjera i uvjerenje priječe obavljanje određenog segmenta njihove profesionalne djelatnosti. Naime, to im pravo dopušta da ne obavljaju određene poslove na svojim radnim mjestima, obavljanje kojih bi ih dovelo u izravan konflikt s njihovom vjerom i uvjerenjima. Nadalje, to pravo ujedno prolazi test razmjernosti tereta za poslodavca, što se dalje u tekstu detaljno obrazlaže. Prethodno je u tekstu pojašnjeno kako su ta dva elementa, element prilagodbe i element razmjernosti tereta, bitni elementi pojma razumne prilagodbe.

Pravo na priziv savjesti predstavlja priznavanje identiteta radnika ${ }^{47} \mathrm{Njime}$ se štiti radnikova sloboda vjere i uvjerenja. Razlikuje se od ostalih oblika prilagodbe

odredba austrijskog zakonodavstva nije razmatrana kao oblik razumne prilagodbe jer pravo EU-a ne poznaje razumnu prilagodbu na temelju vjere. Kad bi pravo EU-a i/ili naše nacionalno pravo predviđalo takvu prilagodbu, ne bi bilo potrebe za propisivanjem posebnih blagdana za pojedine vjere kao neradnih dana jer bi se na to imalo pravo na temelju opće odredbe o razumnoj prilagodbi. Sada se, pak, postavlja pitanje usklađenosti čl. 3. Zakona o blagdanima, spomendanima i neradnim danima u Republici Hrvatskoj s presudom u predmetu Cresco jer pravo na neradne dane daje samo radnicima određenih vjeroispovijesti, a ne daje ga radnicima drugih vjeroispovijesti za njihove blagdane. Iz te presude proizlazi kako je takav pristup diskriminirajući. To je dodatni argument za nužnošću unošenja u naše nacionalno zakonodavstvo izričite zakonske odredbe koja bi predviđala obvezu razumne prilagodbe na temelju vjere.

46 Priziv ili prigovor savjesti, prema Valkoviću, jest odbijanje djelovanja prema zakonu u slučaju kada izvršenje čina ili cilj koji taj zakon želi ostvariti nije prihvatljiv, odnosno nije u skladu s moralnom osjetljivošću (vjerskim, moralnim i filozofskim uvjerenjima) osobe koja iznosi priziv. Valković navodi tri elementa priziva savjesti: nenasilno djelovanje, javni karakter priziva savjesti (jer se treba priopćiti) i njegov vrijednosni sadržaj. Valković, J., Priziv savjesti u ginekologiji i perinatologiji, u: Habek, D. i dr. (ur.), Forenzička ginekologija i perinatologija, Medicinska naklada, Zagreb, 2018. str. 264. Slično i Čizmić definira priziv savjesti. Čizmić, J., Pravo zdravstvenih radnika na "priziv savjesti", Zbornik Pravnog fakulteta Sveučilišta u Rijeci, vol. 37, br. 1, 2016. str. 753 - 754. Vidi i: Cesar, S., Priziv savjesti u reproduktivnoj medicini, Cesi, str. 6, https://www.cesi.hr/hr/priziv-savjesti-u-reproduktivnoj-medicini/ (4. srpnja 2019.).

47 Nevezano uz prigovor savjesti Ashiagbor piše o 'pravima na radnom mjestu koja su utemeljena na priznavanju identiteta' radnika (engl. recognition of identity-based rights in the workplace). Ashiagbor, D., Religion and equality in multicultural workplaces: Human rights and anti-discrimination discourses in EU law, u: Bogg, A.; Costello, C.; Davies, A. C. L. (ur.), Research Handbook on EU Labour Law, Edward Elgar, Cheltenham, 2016. str. 422. 
uvjeta rada koji nemaju značajan utjecaj na prava drugih osoba ${ }^{48}$ (npr. od nošenja vjerskih simbola na radnom mjestu). ${ }^{49}$ Zahtjev radnika (zdravstvene struke ili matičara) da ne provode određene poslove, koji pripadaju u opis njihovih radnih mjesta, šteti osobama s kojima se oni susreću u redovitom obavljanju svoje djelatnosti (pacijentima u slučaju zdravstvenih radnika, odnosno istospolnim partnerima u slučaju matičara nadležnog za sklapanje životnog partnerstva osoba istog spola). ${ }^{50}$ Upravo zbog štetnih posljedica koje priziv savjesti stvara za druge (priziv savjesti uskraćuje drugima pravovremeni pristup usluzi, a može štetiti i dostojanstvu onih kojima je uskraćena ili odbijena usluga) $)^{51}$, granice priziva savjesti moraju jasno biti definirane. Granice su nužne jer pravo na priziv savjesti nije apsolutno, ono mora biti pažljivo uređeno zakonom da se postigne ravnoteža interesa tražitelja usluge koja im je zakonom zajamčena i prava radnika na prilagodbu uvjeta rada njihovoj vjeri i uvjerenjima.

Jesu li granice jasno i adekvatno definirane našim nacionalnim propisima? ${ }^{52}$ Ograničenja prava na priziv savjesti ${ }^{53}$ moraju biti u skladu s međunarodnim standardima (u skladu s čl. 18. st. 3. Međunarodnog pakta o građanskim i

48 Sličan stav popraćen različitim primjerima prilagodbe uvjeta rada pripadnicima vjerskih manjina vidi kod: Ryder, B., Physicians' Rights to Conscientious Objection, u: Berger, B. L.; Moon, R. (ur.), Religion and the Exercise of Public Authority, Bloomsbury, Oxford and Portland, 2016., str. 130. Ryder ukazuje i na ranjiv položaj pacijenata kojima treba zdravstvena usluga, dok su liječnici u poziciji moći i predstavljaju autoritet zbog svojeg statusa i znanja. Zato bi se liječnici trebali suzdržati od promoviranja vlastitih uvjerenja. I navedeno treba imati u vidu pri definiranju granica priziva savjesti. Ryder, op. cit., str. 132 i 137.

49 Vidi predmet o kojem je odlučio Sud za ljudska prava Eweida and others v UK, 48420/10, 59842/10 i 36516/10 (ECHR 25. 5. 2013.).

50 Vidi Zakon o životnom partnerstvu osoba istog spola (Narodne novine, br. 92/2014, 98/2019).

51 Slično u: Ryder, op. cit. u bilj. 48, str. 131 i 132. Navedeno je posebno problematično što se prizivom savjesti perpetuira nepovoljni položaj pripadnika skupina koje su u raznim područjima društvenog života ionako u nepovoljnom položaju (žene, LGBTQ osobe). Time im se otežava ostvarivanje prava za koja su se teškom mukom izborili (pobačaj / sklapanje životnog partnerstva istospolnih parova). Slično navodi Ryder citirajući NeJaime i Siegel. Ryder, op. cit. u bilj. 48, str. 132.

52 Sugestije za unapređenje zakonskih odredaba o prizivu savjesti u nas vidi u: Čizmić, op. cit. u bilj. 46, str. 753 - 786.

53 Vidi o tome stav Vijeća EU-a u: Council of the European Union, Foreign Affairs Council Meeting, EU Guidelines on the Promotion and Protection of Religion or Belief, 2013., https://eeas.europa.eu/sites/eeas/files/137585.pdf (11. srpnja 2019.). 
političkim pravima) ${ }^{54}$ i usko protumačena: moraju biti propisana zakonom i prijeko potrebna radi zaštite javne sigurnosti, reda, zdravlja ili morala, ili temeljnih prava i sloboda drugih. ${ }^{55}$ Ograničenja moraju biti razmjerna potrebi zbog koje su ustanovljena. ${ }^{56}$

Pogledajmo kako se prema prizivu savjesti odnosi naš zakonodavac. U nas je to pravo zajamčeno sljedećim odredbama: čl. 20. Zakona o liječništvu ${ }^{57}$, čl. 3. st. 4. Zakona o sestrinstvu ${ }^{58}$, čl. 26. Zakona o dentalnoj medicini ${ }^{59}$ i čl. 44.

54 Iako Međunarodni pakt o građanskim i političkim pravima izrijekom ne spominje priziv savjesti, nadzorno tijelo (UN Human Rights Committee) drži da ono proizlazi iz čl. 18. tog pakta. UN Human Righs Committee, CCPR General Comment No. 22: Article 18 (Freedom of Thought, Conscience or Religion), 1993., str. 3, https://www. refworld.org/docid/453883fb22.html (11. srpnja 2019.).

55 U kontekstu prava drugih kao granice provođenja razumne prilagodbe treba spomenuti kako u Ujedinjenom Kraljevstvu zakonodavac ne dopušta priziv savjesti za matičare, već su obvezni vjenčavati istospolne parove. Vickers, L., Conscientious Objections in Employment: Is a Duty of Reasonable Accommodation the Answer?, u: Adentire, J., Religious Beliefs and Conscientious Exemptions in a Liberal State, Hart, Oxford, 2019., str. 199.

56 UN Human Righs Committee, op. cit. u bilj. 54, str. 3, https:/www.refworld.org/ docid/453883fb22.html (5. svibnja 2020.).

57 Zakon o liječništvu (Narodne novine, br. 121/2003, 117/2008). Čl. 20. glasi: “(1) Radi svojih etičkih, vjerskih ili moralnih nazora, odnosno uvjerenja liječnik se ima pravo pozvati na priziv savjesti te odbiti provođenje dijagnostike, liječenja i rehabilitacije pacijenta, ako se to ne kosi s pravilima struke te ako time ne uzrokuje trajne posljedice za zdravlje ili ne ugrozi život pacijenta. O svojoj odluci mora pravodobno izvijestiti pacijenta te ga uputiti drugom liječniku iste struke. (2) Ako je liječnik zaposlen u zdravstvenoj ustanovi, trgovačkom društvu, odnosno drugoj pravnoj osobi koja obavlja zdravstvenu djelatnost ili kod drugog liječnika koji obavlja privatnu praksu, mora o odluci izvijestiti svog nadređenog, odnosno poslodavca."

58 Zakon o sestrinstvu (Narodne novine, br. 121/2003, 117/2008 i 57/2011). Čl. 3. st. 4. Zakona o sestrinstvu glasi: "Radi svojih etičkih, vjerskih ili moralnih nazora, odnosno uvjerenja medicinska sestra se ima pravo pozvati na priziv savjesti te odbiti provođenje zdravstvene/sestrinske njege ako se to ne kosi s pravilima struke te ako time ne uzrokuje trajne posljedice za zdravlje ili ne ugrozi život pacijenta. O svojoj odluci mora pravodobno izvijestiti pacijenta i odgovornu ili nadređenu osobu."

59 Zakon o dentalnoj medicini (Narodne novine, br. 121/2003, 117/2008 i 120/2009). Čl. 26. glasi: “(1) Radi svojih etičkih, vjerskih ili moralnih nazora, odnosno uvjerenja doktor dentalne medicine se ima pravo pozvati na priziv savjesti te odbiti provođenje dijagnostike, liječenja i rehabilitacije pacijenta, ako se to ne kosi s pravilima struke te ako time ne uzrokuje trajne posljedice za zdravlje ili ne ugrozi život pacijenta. O svojoj odluci mora pravovremeno izvijestiti pacijenta te ga uputiti drugom doktoru dentalne medicine iste struke. (2) Ako je doktor dentalne medicine zaposlen kod drugog doktora dentalne medicine koji obavlja privatnu praksu ili u 
Zakona o medicinski pomognutoj oplodnji. ${ }^{60}$ Analizom sadržaja navedenih odredaba zaključujem da su odredbe analognog sadržaja, uz iznimku Zakona o medicinski pomognutoj oplodnji, koji jedini ne sadržava ograničenja priziva. Svi ostali navedeni zakoni sadržavaju sljedeća ograničenja priziva savjesti: ne smije se kositi s pravilima struke; ne smije uzrokovati trajne posljedice za zdravlje; ne smije ugroziti život pacijenta; pravodobno se mora pacijenta izvijestiti o odluci koja predstavlja manifestaciju priziva savjesti; zdravstveni radnik (liječnik i liječnik dentalne medicine, dok medicinske sestre nemaju tu obvezu) koji se poziva na priziv savjesti mora pacijenta uputiti drugom liječniku iste struke; onaj koji se poziva na priziv mora o odluci izvijestiti nadređenog, odnosno poslodavca (medicinske sestre mogu izvijestiti, osim nadređene osobe, i odgovornu osobu). U pojedinim segmentima uređenja granica priziva savjesti, zaključujem, zakonodavac štiti slobodu vjere i uvjerenja zdravstvenog radnika u tolikoj mjeri da (čak) i u slučaju kada priziv savjesti uzrokuje privremene posljedice za zdravlje pacijenta, takvu posljedicu smatra dopuštenom. Osim toga, manjkavošću uređenja priziva savjeti smatram i odredbu koja obvezuje zdravstvenog radnika koji se poziva na priziv savjesti da uputi pacijenta drugom liječniku iste struke. Naime, ta obveza nije jasno definirana jer ako se pacijenta uputi liječniku iste struke koji se također poziva na priziv savjesti, pacijent neće dobiti zdravstvenu uslugu koja mu po zakonu pripada, a čini se da bi, leksičkim tumačenjem, takav postupak bio usklađen s dikcijom odredbe i predstavljao bi ispunjenje obveze. Navedenu odredbu trebalo bi ili teleološki tumačiti na način da predstavlja obvezu zdravstvenog radnika da pacijenta uputi zdravstvenom radniku koji se ne poziva na priziv savjesti, ili bi odredbu trebalo dopuniti na način da je zdravstveni radnik obvezan uputiti pacijenta zdravstvenom radniku iste struke koji se ne poziva na priziv savjesti. U svakom slučaju zdravstveni radnici morali bi imati saznanja tko se od njih poziva na priziv savjesti, a tko ne, kako bi pacijentu mogli dati odgovarajuću informaciju.

zdravstvenoj ustanovi, odnosno u drugoj pravnoj osobi, mora o odluci izvijestiti svoga nadređenog, odnosno poslodavca."

60 Zakon o medicinski pomognutoj oplodnji (Narodne novine, br. 86/2012) u čl. 44. navodi sljedeće: “Zdravstveni radnici i nezdravstveni radnici koji bi trebali provesti ili sudjelovati u provođenju postupaka medicinski pomognute oplodnje imaju pravo pozvati se na priziv savjesti zbog svojih etičkih, vjerskih ili moralnih nazora, odnosno uvjerenja te odbiti provođenje postupaka medicinski pomognute oplodnje ili sudjelovanje u tom postupku." 
U nas postoje zdravstvene ustanove $u$ kojima se velik broj zdravstvenih radnika (ili čak svi) ${ }^{61}$ poziva na odredbe o prizivu savjesti. Navedene odredbe, treba reći, ipak su krojene na način da predstavljaju iznimku, a ne pravilo, jer u suprotnom pacijent ne može dobiti zdravstvenu uslugu na koju po zakonu ima pravo. Zbog toga se otvara pitanje što kada priziv savjesti postane pravilo i značajno otežava (ili čak onemogućuje) pacijentima ostvarivanje zdravstvenih usluga koje se protive vjeri i uvjerenju zdravstvenih radnika. Moraju li zdravstvene ustanove imati dovoljan broj zdravstvenih radnika koji se ne pozivaju na priziv savjesti te, ako moraju, kako to osigurati? S obzirom da zakonom zajamčena zdravstvena usluga mora biti dostupna pacijentima, tamo gdje je to, zbog prevelikog broja onih koji se pozivaju na priziv savjesti, značajno otežano ili onemogućeno, pri zasnivanju radnog odnosa morat će se kao stvarni i odlučujući uvjet za obavljanje posla postaviti zahtjev da je zdravstveni radnik u mogućnosti obavljati sve poslove toga radnog mjesta, bez pozivanja na priziv savjesti. ${ }^{62}$ Tako bi se osigurao dovoljan broj zdravstvenih radnika dostatnih za uredno funkcioniranje zdravstvene ustanove i pružanje pacijentima svih zakonom definiranih zdravstvenih usluga.

\section{RAZUMNA PRILAGODBA U ANGLOSAKSONSKOM PRAVNOM KRUGU}

U SAD- $\mathrm{u}^{63}$ i Kanadi koncept razumne prilagodbe najprije se pojavio u antidiskriminacijskom pravu kao odgovor na različitost vjera. ${ }^{64}$ Danas $\mathrm{u}$ Kanadi postoji obveza razumne prilagodbe za osobe s invaliditetom i osobe različitih vjera, nacionalnog porijekla i dobi ${ }^{65}$, dok se u SAD-u razumna prilagodba provodi s

${ }_{61}$ Barišić, I., Poplava priziva savjesti: U jednoj zagrebačkoj bolnici svi ginekolozi 'prizivači', pogledajte kako stvari stoje u ostatku Hrvatske, Tportal, 1. travnja 2019., https://www.tportal.hr/vijesti/clanak/poplava-priziva-savjesti-u-jednoj-zagrebackoj-bolnici-svi-ginekolozi-prizivaci-pogledajte-kako-stvari-stoje-u-ostatku-hrvatske-20190401 (16. srpnja 2019.).

${ }^{62}$ O stvarnom i odlučujućem uvjetu kao iznimci od zabrane izravne diskriminacije vidi u: Potočnjak; Grgić, op. cit. u bilj. 14, str. 176 i 177.

63 SAD je prva država na svijetu koja je uvela zakonsku obvezu razumne prilagodbe, najprije na osnovi vjere, a nakon toga na osnovi invaliditeta. Bribosia; Rorive, op. cit. u bilj. 1, str. 12 .

64 Bribosia; Rorive, op. cit. u bilj. 1, str. 5.

65 Bribosia; Rorive, op. cit. u bilj. 1, str. 15. Ističem kako i pojedine europske države predviđaju razumnu prilagodbu za mlade radnike (tako je u Bugarskoj i Finskoj, a određene oblike takve prilagodbe poznaje i naše zakonodavstvo - vidi više u bilj. 
obzirom na etničku pripadnost, dob, obiteljski status, spol i trudnoću. ${ }^{66} \mathrm{U}$ ovom dijelu rada pažnja će se posvetiti razumnoj prilagodbi za osobe s invaliditetom i za radnike vjernike onako kako se ona razumijeva u anglosaksonskom pravu.

\subsection{Razumna prilagodba za osobe $s$ invaliditetom}

U predmetu Archibald v Fife Council iz 2004. ${ }^{67}$, iz engleske sudske prakse, trebalo je utvrditi postoji li obveza poslodavca da zaposli radnicu kod koje je nastao invaliditet na drugo slobodno radno mjesto za koje je kvalificirana i koje može obavljati na temelju preostale radne sposobnosti, bez provođenja intervjua i natjecanja s drugim kandidatima. Sud je utvrdio da je to oblik razumne prilagodbe i obveza poslodavca. U presudi u predmetu Chief Constable of South Yorkshire v Jelic iz 2010. ${ }^{68}$ engleski sud ide i korak dalje te presuđuje da obveza poslodavca na razumnu prilagodbu obuhvaća i obvezu zamjene radnih mjesta radnika s invaliditetom s radnikom bez invaliditeta čije radno mjesto odgovara sposobnostima radnika s invaliditetom. U tom je predmetu tužitelj policajac, koji je godinama patio od sindroma kronične anksioznosti, a koji je radio na radnom mjestu koje nije uključivalo javne kontakte. Kad se javila potreba da u okviru svojeg radnog mjesta ima kontakte s klijentima, umirovljen je zbog nemogućnosti da nastavi s radom na tom radnom mjestu. Sud je utvrdio postojanje diskriminacije jer je poslodavac morao omogućiti tužitelju da zamijeni radno mjesto s radnim mjestom drugog zaposlenika. ${ }^{69}$

5) ili za starije radnike (tako je u Makedoniji). Više o tome: Kaya, R., Reasonable Accommodation for Age, Canadian Journal of Law \& Jurisprudence, vol. XXXIII, br. 1, 2020., str. 141 - 142. Detaljnija analiza odredaba usporednopravnih propisa o razumnoj prilagodbi na temelju dobi prelazi okvire ovoga rada.

Ibid.

Archibald v Fife Council iz 2004. UKHL 32. Tekst presude dostupan je na: http:// www.publications.parliament.uk/pa/ld200304/ldjudgmt/jd040701/arch-1.htm (5. svibnja 2020.).

Chief Constable of South Yorkshire v Jelic iz 2010. IRLR 744. Tekst presude dostupan je na: http://www.employmentcasesupdate.co.uk/site.aspx?i=ed4774 (3. svibnja 2020.).

Ovakva obveza poslodavca u nas bi otvorila pitanje oblika otkaza ugovora o radu radnika s kojim radnik s invaliditetom mijenja radno mjesto jer navedeno ne bi pripadalo ni u jedan zakonom definirani opravdani razlog otkazivanja (ni skrivljenim ponašanjem, ni osobno uvjetovan, a ni poslovno uvjetovani otkaz). Vidi čl. 115. ZR-a. 


\subsection{Razumna prilagodba za radnike vjernike}

U SAD-u zakonodavac izrijekom propisuje poslodavcima obvezu razumne prilagodbe za radnike vjernike, ali to za njega ne smije predstavljati nerazmjeran (stvaran, a ne samo hipotetski) teret. ${ }^{70} \mathrm{Za}$ razliku od, prethodno u tekstu pojašnjene, engleske sudske prakse, u kojoj se razumna prilagodba (za osobe $\mathrm{s}$ invaliditetom) provodi i zamjenom radnih mjesta, u SAD-u je takav oblik razumne prilagodbe moguć samo ako je dragovoljan. ${ }^{71}$ Otkaz radniku vjerniku dopušten je kada je prebacivanje poslova na njegove kolege nepraktično. Primjer za to je predmet Bruff v North Mississippi Health Service, u kojem je savjetnica, iz vjerskih razloga, odbila savjetovati homoseksualne klijente i izvanbračne partnere. ${ }^{72}$ Sud je zaključio kako je nemoguće unaprijed predvidjeti hoće li se, pri savjetovanju parova, pojaviti pitanje njihove homoseksualnosti ili izvanbračnog partnerstva te kada bi se savjetnicima dopustilo da se isključe iz takvih zadaća, to bi vodilo neravnopravnoj raspodjeli poslova između kolega. ${ }^{73}$

U usporedbi sa širokim mogućnostima opravdavanja poslodavaca u SAD-u da ne provedu razumnu prilagodbu, u Kanadi su prema poslodavcima stroži. Kada radnik zatraži prilagodbu, poslodavac je zahtjev obvezan razmotriti, u suprotnom diskriminira radnika. ${ }^{74}$ I dok i u pravu SAD-a i u kanadskom pravu postoji propisana obveza razumne prilagodbe za radnike vjernike, ti radnici nisu jednako zaštićeni jer sudovi nerazmjeran teret nejednako tumače. Može se zaključiti da razina zaštite radnika od (vjerske) diskriminacije ne ovisi samo o zakonom propisanoj obvezi poslodavaca da provode razumne prilagodbe, već primarno o tumačenju pojma nerazmjernog tereta od strane sudova. Očito, kada sudovi poslodavcima daju široke mogućnosti opravdavanja nerazmjernog tereta (kao što je o slučaj u SAD-u), zaštita radnika vjernika bit će slabija. ${ }^{75}$

$\mathrm{U}$ anglosaksonskom pravnom krugu različita nacionalna zakonodavstva različito uređuju priziv savjesti. Dok se u engleskom pravu priziv savjesti osigurava

70 Title VII of the Civil Rights Act, 1964., https://www.justice.gov/crt/combating-religious-discrimination-and-protecting-religious-freedom-16 (20. travnja 2020.). Vidi više u: Vickers, op. cit. u bilj. 55, str. 195.

71 Engl. voluntary swaps of tasks. Ibid.

72 Bruff v North Mississippi Health Service, 244 F 3d 495, 2001., https://caselaw.findlaw. com/us-5th-circuit/1453488.html (20. travnja 2020.).

73 Ibid.

74 Vickers, op. cit. u bilj. 55, str. 195.

75 Slično Vickers, op. cit. u bilj. 55, str. 199. 
kroz koncept neizravne diskriminacije, u SAD-u i Kanadi ${ }^{76}$ on se jamči kroz koncept razumne prilagodbe. Prema Vickers, učinak je isti, odnosno postiže se ista razina zaštite, iako su putovi postizanja zaštite različiti. ${ }^{77}$ Dok se kod koncepta neizravne diskriminacije razmatra proporcionalnost mjere (je li ona odgovarajuća i nužna za postizanje legitimnog cilja), dotle se kod koncepta razumne prilagodbe ocjenjuje je li teret za poslodavca nerazmjeran. Vickers zaključuje kako je priziv savjesti u engleskom pravu i dalje potrebno razmatrati kroz koncept neizravne diskriminacije jer bi propisivanje razumne prilagodbe za radnike vjernike dalo vjeri privilegiran status u odnosu na druge zaštićene interese (osnove diskriminacije). ${ }^{78} \mathrm{Za}$ naše pravo smatram prikladnijim razmatranje priziva savjesti kroz koncept razumne prilagodbe. Naime, neizravna diskriminacija je složen koncept razumljiv tek verziranim pravnicima. Da bi dokazao postojanje prima facie neizravne diskriminacije na osnovi vjere, radnik mora učiniti vjerojatnim da neka naizgled neutralna odredba, kriterij ili praksa stavlja ili bi mogla staviti osobe (množina!) u nepovoljniji položaj po osnovi vjere. ${ }^{79}$ S druge strane, razumna prilagodba je jednostavan koncept prema kojem radnik traži od poslodavca prilagodbu, a na poslodavcu je da dokazuje da je teret prilagodbe nerazmjeran. ${ }^{80}$ Zbog navedenog, držim da je koncept razumne prilagodbe lakši i jednostavniji put zaštite radnika vjernika te da postojeće uređenje priziva savjesti u našem nacionalnom zakonodavstvu po svojim elementima odgovara pojmu razumne prilagodbe, iako ga zakonodavac takvim nije izrijekom nazvao. ${ }^{81}$

76 O tome kako je u kanadskom pravu uređen priziv savjesti liječnika vidi u: Ryder, op. cit. u bilj. 48, str. $127-147$.

77 Vickers, op. cit. u bilj. 55, str. 203.

78 Ibid.

79 Čl. 2. st. 2. ZSD-a.

80 Argument iz čl. 4. st. 2. ZSD-a. Detaljnije o razlikama između neizravne diskriminacije i razumne prilagodbe u: Vickers, op. cit. u bilj. 55, str. $200-201$.

81 Iako usporedba s njemačkih pravom nije predmet ovog rada, vrijedi spomenuti kako i njemački pravni teoretičari upozoravaju na manjkavost njemačkog antidiskriminacijskog prava koje nema razvijen koncept razumne prilagodbe izvan konteksta invaliditeta. Tako Eichenhofer predlaže da se čl. 1. Allgemeines Gleichbehandlungsgesetz (Općeg zakona o ravnopravnosti) predvidi obveza razumne prilagodbe po svim zabranjenim osnovama diskriminacije predviđenim tom odredbom (rasa, etničko podrijetlo, spol, vjera i uvjerenje, invaliditet, dob i spolna orijentacija). Tekst odredbe dostupan na: https://www.gesetze-im-internet.de/agg/__l.html (4. svibnja 2020.). Eichenhofer, E., Angemessene Vorkehrungen als Diskrieminirungsdimension im Recht, Nomos, Baden-Baden, 2018., https://www.antidiskriminierungsstelle.de/SharedDocs/Downloads/DE/publikationen/Factsheets/factsheet_Angemessene_Vorkehrungen.pdf?_blob=publicationFile\&v=2 (4. svibnja 2020.). 


\section{ZAKLJUČAK}

Koncept razumne prilagodbe bit će i dalje marginaliziran, bez osvješćivanja poslodavaca o njihovoj obvezi razumne prilagodbe. Pretpostavka za adekvatnu razumnu prilagodbu jest razumijevanje od strane poslodavaca kruga zaštićenih osoba i mjera koje pripadaju u tu obvezu.

Zbog razlike u opsegu zabrane diskriminacije na osnovi invaliditeta u $\mathrm{Hr}-$ vatskoj i EU-u, pozitivna iskustva treba tražiti u usporednim nacionalnim zakonodavstvima i praksi, ponajprije u anglosaksonskom pravnom krugu, u kojem pojedina zakonodavstva obvezu razumne prilagodbe razvijaju već desetljećima, proširivši je i na druge ranjive skupine.

Analizom domaćeg zakonodavstva i prava EU-a dolazi se do zaključka da, iako ih se ne naziva razumnom prilagodbom, pojedini oblici razumne prilagodbe već su propisima zajamčeni, osim osobama s invaliditetom, i pripadnicima ostalih ranjivih skupina (radnicima vjernicima, trudnicama, roditeljima, radnicima s obiteljskim obvezama, maloljetnicima). U tom kontekstu analizirane su odredbe domaćeg zakonodavstva koje uređuju priziv savjesti te su istaknute njihove manjkavosti, s osobitim naglaskom na nerazmjernost tereta kao granici prava na priziv savjesti. Kako domaći zakonodavac segmentarno pristupa prilagodbi mjesta i uvjeta rada, radi cjelovite zaštite ranjivih skupina, smjer u kojem bi naš zakonodavac trebao ići jest revaloriziranje pojma razumne prilagodbe na način da proširi obvezu razumne prilagodbe izrijekom i na druge zabranjene osnove diskriminacije poput vjere, dobi i obiteljskog statusa. Zakonska odredba kojom bi se obveza poslodavca na razumnu prilagodbu na predloženi način proširila, ne bi trebala biti otegotna za poslodavce jer je razmjernost tereta sastavni dio pojma razumne prilagodbe. Dakle, poslodavci bi bili zaštićeni nerazmjernim teretom kao granicom svojih obveza prema radnicima pripadnicima ranjivih skupina.

Konačno, treba reći kako bi se pravilnim tumačenjem čl. 7. st. 4. Zakona o radu, koji predviđa zabranu diskriminacije kao jednu od temeljnih obveza poslodavca iz radnog odnosa, trebalo zaključiti kako je poslodavac obvezan provoditi razumnu prilagodbu po svim zabranjenim osnovama diskriminacije. Ipak, radi transparentnosti te obveze, širenjem kruga osoba, kojima se jamči razumna prilagodba mjesta i uvjeta rada, izričitom zakonskom odredbom, zakonodavac bi "osigurao različitosti na radnom mjestu, ne samo prevencijom diskriminacije već i aktivnim promicanjem različitosti." ${ }^{82}$ Nadalje, društvena

82 Estlund, C., Working Together: How Workplace Bonds Strengthen a Diverse Democracy, citirano prema: Davidov, G., A purposive approach to labour law, Oxford University Press, Oxford, 2016., str. 63. 
uključenost ostvarena u svijetu rada teško se može izolirati (u smislu isključive vezanosti uz radno mjesto). Kada se postigne na radnom mjestu, može se očekivati da će se proširiti i na druga područja društvenog života, izvan radnog mjesta. ${ }^{83}$ Obrasce ponašanja stečene na radnom mjestu radnici preuzimaju i prenose u druga područja svojega djelovanja. Potencijal unapređenja društva i izvan sfere svojeg (naizgled uskog) područja djelovanja dodana je vrijednost (antidiskriminacijskog) radnog prava.

\section{LITERATURA}

\section{Knjige i časopisi:}

Ashiagbor, D., Religion and equality in multicultural workplaces: Human rights and anti-discrimination discourses in EU law, u: Bogg, A.; Costello, C.; Davies, A. C. L. (ur.), Research Handbook on EU Labour Law, Edward Elgar, Cheltenham, 2016., str. 422-444.

Barnard, C., EU Employment Law, Fourth Edition, Oxford University Press, Oxford, 2012.

Bejaković, P., Studija isplativosti profesionalne rehabilitacije u Republici Hrvatskoj, Fond za profesionalnu rehabilitaciju i zapošljavanje osoba s invaliditetom, Zagreb, 2013.

Bribosia, E.; Rorive, I., Reasonable Accommodation beyond Disability in Europe, European Commission, 2013., http://ec.europa.eu/justice/discrimination/files/ reasonable_accommodation_beyond_disability_in_europe_en.pdf

Cesar, S., Priziv savjesti u reproduktivnoj medicini, Cesi, https://www.cesi.hr/hr/ priziv-savjesti-u-reproduktivnoj-medicini/

Čizmić, J., Pravo zdravstvenih radnika na „priziv savjesti“, Zbornik Pravnog fakulteta Sveučilišta u Rijeci, vol. 37, br. 1, 2016., str. 753-786.

Davidov, G., A purposive approach to labour law, Oxford University Press, Oxford, 2016.

De Schutter, O., International Human Rights Law, Second Edition, Cambridge University Press, Cambridge, 2014.

83 Davidov piše o integrativnoj ulozi radnog prava. Po njemu radno pravo ne teži samo društvenoj uključenosti na radnom mjestu već i oblikovanju radnog mjesta kao mjesta civilnog društva koje podupire integraciju i društveni angažman i izvan radnog mjesta. Davidov, op. cit. u bilj. 82, str. 64. 
Eichenhofer, E., Angemessene Vorkehrungen als Diskrieminirungsdimension im Recht, Nomos, Baden-Baden, 2018.

Fredman, S., Discrimination Law, Second Edition, Oxford University Press, Oxford, 2011.

Fredman, S., Pasts and futures: EU equality law, u: Bogg, A.; Costello, C.; Davies A. C. L. (ur.), Research Handbook on EU Law, Edward Elgar, Cheltenham, 2016., str. 391-421.

Grgurev, I., Diskriminacija na temelju tjelesnih ili duševnih poteškoća u radnom pravu, Zbornik Pravnog fakulteta u Zagrebu, vol. 54, br. 3-4, 2004., str. 651-679.

Kaya, R., Reasonable Accommodation for Age, Canadian Journal of Law \& Jurisprudence, vol. XXXIII, br. 1, 2020., str. 115-143.

Potočnjak, Ž.; Grgić, A., Izuzeci i opravdanja kod zabrane diskriminacije, u: Potočnjak, Ž.; Grgurev, I.; Grgić, A. (ur.), Perspektive antidiskriminacijskog prava, Pravni fakultet Sveučilišta u Zagrebu, Zagreb, 2014., str. 153-197.

Potočnjak, Ž.; Grgić, A., Osnovni pojmovi i koncepcije o zabrani diskriminacije u radnom pravu, u: Potočnjak, Ž.; Grgurev, I.; Grgić, A. (ur.), Perspektive antidiskriminacijskog prava, Pravni fakultet Sveučilišta u Zagrebu, Zagreb, 2014., str. 1-48.

Quinne, G.; Waddington, L. (ur.), European Yearbook of Disability Law, sv. 1, Intersentia, Antwerp, 2009.

Ryder, B., Physicians' Rights to Conscientious Objection, u: Berger, B. L.; Moon, R. (ur.), Religion and the Exercise of Public Authority, Bloomsbury, Oxford and Portland, 2016., str. 127-147.

Somek, A., Rationalität und Diskriminierung, Springer, Wien, 2001.

Valković, J., Priziv savjesti u ginekologiji i perinatologiji, u: Habek, D. i dr. (ur.), Forenzička ginekologija i perinatologija, Medicinska naklada, Zagreb, 2018., str. 263-279.

Vasiljević, S., Pravno uređenje višestruke diskriminacije u proširenoj Europskoj uniji (doktorska disertacija), Pravni fakultet Sveučilišta u Zagrebu, Zagreb, 2008.

Vasiljević, S.; Vinković, M., Temeljna prava i zabrana diskriminacije u praksi europskih i nacionalnih sudova, Narodne novine, Zagreb, 2019.

Vickers, L., Conscientious Objections in Employment: Is a Duty of Reasonable Accommodation the Answer?, u: Adenitire, J. (ur.), Religious Beliefs and Conscientious Exemptions in a Liberal State, Hart, Oxford, 2019., str. 185-204.

Waddington, L.; Broderick, A., Combatting disability discrimination and realising equality, A comparison of the UN Convention on the Rights of Persons with Disabilities and EU equality and non-discrimination law, European Commission, 2018.

Zatz, N. D., Discrimination and Labour Law: Locating the Market in Maldistribution and Subordination, u: Collins, H.; Lester, G.; Mantouvalou, V. (ur.), Philosophical Foundations of Labour Law, Oxford University Press, Oxford, 2018., str. 156-174. 


\section{Pravni akti:}

Allgemeines Gleichbehandlungsgesetz, https://www.gesetze-im-internet.de/agg/ Americans with Disability Act, http://www.ada.gov/pubs/adastatute08.htm

Civil Rights Act, 1964, https://www.justice.gov/crt/combating-religious-discrimination-and-protecting-religious-freedom-16

Direktiva Vijeća 92/85/EEZ od 19. listopada 1992. o uvođenju mjera za poticanje poboljšanja sigurnosti i zdravlja na radu trudnih radnica te radnica koje su nedavno rodile ili doje, OJ L 348, 28. studenog 1992., str. 1-7.

Direktiva Vijeća 2000/43/EZ od 29. lipnja 2000. o provedbi načela jednakog postupanja prema osobama bez obzira na njihovo rasno ili etničko podrijetlo, OJ L 180, 19. srpnja 2000., str. 19.-23.

Direktiva Vijeća 2000/78/EZ od 27. studenoga 2000. o uspostavi općeg okvira za jednako postupanje pri zapošljavanju i obavljanju zanimanja, SL 303/16, 2. prosinca 2000., 05/Sv. 1, str. 69-75.

Direktiva 2006/54/EZ Europskog parlamenta i Vijeća od 5. srpnja 2006. o provedbi načela jednakih mogućnosti i jednakog postupanja prema muškarcima i ženama u pitanjima zapošljavanja i rada (preinaka), OJ L 204, 26. srpnja 2006., str. 23-26.

Direktiva (EU) 2019/1158 Europskog parlamenta i Vijeća od 20.6.2019. o ravnoteži između poslovnog i privatnog života roditelja i pružatelja skrbi i o stavljanju izvan snage Direktive Vijeća 2010/18/EU, OJ L 188, 12. srpnja 2019., str. 79-93.

Konvencija Međunarodne organizacije rada o nasilju i uznemiravanju br. 190 i Preporuka br. 206 o nasilju i uznemiravanju,

https://www.ilo.org/dyn/normlex/en/f?p=NORMLEXPUB:12100:0::NO:::

https://www.ilo.org/dyn/normlex/en/f?p=NORMLEXPUB:12100:0::NO:: P12100_ILO_CODE:R206

Konvencija o pravima osoba s invaliditetom (Narodne novine, Međunarodni ugovori, br. 6/2007, 3/2008, 5/2008)

Zakon o blagdanima, spomendanima i neradnim danima u Republici Hrvatskoj (Narodne novine, br. 110/2019)

Zakon o dentalnoj medicini (Narodne novine, br. 121/2003, 117/2008, 120/2009)

Zakon o liječništvu (Narodne novine, br. 121/2003, 117/2008)

Zakon o medicinski pomognutoj oplodnji (Narodne novine, br. 86/2012)

Zakon o profesionalnoj rehabilitaciji i zapošljavanju osoba s invaliditetom (Narodne novine, br. 153/2013, 152/2014, 39/2018, 32/2020) 
Zakon o radu (Narodne novine, br. 93/2014, 127/2017, 98/2019)

Zakon o sestrinstvu (Narodne novine, br. 121/2003, 117/2008 i 57/2011)

Zakon o suzbijanju diskriminacije (Narodne novine, br. 85/2008, 112/2012)

Zakon o životnom partnerstvu osoba istog spola (Narodne novine, br. 92/2014, 98/2019)

\section{Sudska praksa:}

Achbita, C-157/15, ECLI:EU:C:2017:203.

Archibald v Fife Council od 1. srpnja 2004., (2004) UKHL 32

Bougnaoui, C-188/15, ECLI:EU:C:2017:204

Bruff v North Mississippi Health Service 244 F 3d 495 (2001)

Chacón Navas, C-13/05, ECLI:EU:C:2006:456

Chief Constable of South Yorkshire v Jelic od 29. travnja 2010., (2010) IRLR 744

Cresco, C-193/17, ECLI:EU:C:2019:43

Daoudi, C-395/15, ECLI:EU:C:2016:917

Eweida and others v UK, 48420/10, 59842/10 i 36516/10 (ECHR 25.5.2013.).

HK Danmark C-335/11 i C-337/11, ECLI:EU:C:2013:222

Kaltoft, C-354/13, ECLI:EU:C:2014:2463

Županijski sud u Puli, Gž-67/17-2, 27.3.2017.

Županijski sud u Zagrebu, Gžr-1708/16-2, 20.12.2016.

\section{Ostalo:}

Barišić, I., Poplava priziva savjesti: U jednoj zagrebačkoj bolnici svi ginekolozi 'prizivači', pogledajte kako stvari stoje u ostatku Hrvatske, Tportal, 1. travnja 2019., https:// www.tportal.hr/vijesti/clanak/poplava-priziva-savjesti-u-jednoj-zagrebackoj-bolnici-svi-ginekolozi-prizivaci-pogledajte-kako-stvari-stoje-u-ostatku-hrvatske-20190401

Council of the European Union, Foreign Affairs Council Meeting, EU Guidelines on the Promotion and Protection of Religion or Belief, 2013., https://eeas.europa. eu/sites/eeas/files/137585.pdf

Priručnik preporuka za razumnu prilagodbu radnog mjesta, Zavod za vještačenje, profesionalnu rehabilitaciju i zapošljavanje osoba s invaliditetom i Ministarstvo rada i mirovinskog sustava, 2018., https://www.zosi.hr/docs/ prirucnik_s_preporukama_za_razumnu_prilagodbu_radnog_mjesta.pdf 
Proposal for a Council Directive on implementing the principle of equal treatment between persons irrespective of religion or belief, disability, age or sexual orientation SEC(2008)2180, http://eur-lex.europa.eu/legal-content/en/ TXT/?uri=CELEX:52008PC0426

Rezolucija 2076 Parlamentarne skupštine Vijeća Europe od 30.9.2015., Freedom of religion and living together in a democratic society, https://assembly.coe.int/nw/ xml/XRef/Xref-XML2HTML-en.asp?fileid=22199\&lang=en

UN Human Righs Committee, CCPR General Comment No. 22: Article 18 (Freedom of Thought, Conscience or Religion), 1993., https://www.refworld.org/ $\mathrm{docid} / 453883 \mathrm{fb} 22 . \mathrm{html}$

Workplace Accommodations: Low Cost, High Impact, Job Accommodation Network, ODEP, 2019., https://askjan.org/publications/Topic-Downloads. cfm?pubid $=962628$ 


\section{Summary}

\section{Ivana Grgurev*}

\section{THE REACH OF REASONABLE ACCOMMODATION (IN DOMESTIC, ANGLO-SAXON AND EU LAW)}

Based on the acquis communautaire, the legislator in the Republic of Croatia explicitly refers to the concept of reasonable accommodation solely for persons with disabilities. Considering the development of anti-discrimination law, this paper starts with the thesis that, for the sake of transparency and better protection, the law should expressly stipulate that this term has been extended to other vulnerable groups. This paper analyzes employers' obligations regarding the adaptation of workplaces and working conditions to employees with disabilities, as well as employees belonging to other vulnerable groups (employees with religious beliefs and employees with family responsibilities). The topic is approached by a comparative method, pointing to solutions from the Anglo-Saxon legal circle. In the section dealing with European Union law, attention is paid to recent legislation and the case law of the Court of Justice of the European Union to demonstrate that, when it comes to reasonable accommodation, EU law is gradually being opened up to employees with family responsibilities and employees with religious beliefs. The paper pays special attention to the conscientious objection, which, to date, has not been approached as a form of reasonable accommodation in the domestic legal theory.

Keywords: reasonable accommodation; discrimination; conscientious objection; AngloSaxon legal circle; EU law

* Ivana Grgurev, Ph. D., Professor, Faculty of Law, University of Zagreb, Trg Republike Hrvatske 14, 10000 Zagreb, Croatia; ivana.grgurev@pravo.hr;

ORCID ID: orcid.org/0000-0001-5543-8518 